JOURNAL OF MANAGEMENT OF AQUATIC RESOURCES

Volume 2, Nomor 3, Tahun 2013, Halaman 180-189

Online di : http://ejournal-s1.undip.ac.id/index.php/maquares

\title{
IDENTIFIKASI SUMBERDAYA KEPITING BAKAU (Scylla sp.) YANG DIDARATKAN DI TPI KABUPATEN TAPANULI TENGAH
}

\section{Roswita Larosa, Boedi Hendrarto, Mustofa Nitisupardjo*)}

Jurusan Perikanan, Fakultas Perikanan dan Ilmu Kelautan, Universitas Diponegoro

Jl. Prof. H. Soedharto, SH, Tembalang Semarang. 50275 Telp/Fax (024) 7474698

\begin{abstract}
Abstrak
Salah satu sumberdaya perikanan di wilayah perairan Indonesia adalah kepiting bakau namun informasi mengenai keberadaan kepiting bakau khususnya jenis-jenisnya masih terbatas begitu juga pada wilayah perairan Kabupaten Tapanuli Tengah. Untuk mengatasi permasalahan tersebut perlu dilakukan identifikasi jenis morfologi kepiting bakau.

Penelitian yang dilaksanakan pada bulan Januari-Februari 2011 ini adalah untuk mengetahui jenis dan morfologi kepiting bakau, kelimpahan dan dominasi kepiting bakau, serta mengetahui nilai komersil kepiting bakau di wilayah Kabupaten Tapanuli Tengah Sumatera Utara. Sampel yang diteliti adalah kepiting bakau yang didaratkan di 3 (tiga) TPI yaitu Desa Hajoran, Desa Poriaha dan Desa Sijago-jago Kabupaten Tapanuli Tengah. Kepiting yang tertangkap oleh nelayan diidentifikasi dan dilakukan pengukuran morfometrik kemudian menganalisis data yang didapatkan, dan wawancara nelayan untuk mengetahui berat komersil dan kisaran harga kepiting bakau tersebut. Jumlah spesies kepiting bakau yang ditemukan adalah 3 (tiga) spesies yaitu Scylla serrata (63.41\%), Scylla olivacea (26.22 \%), dan Scylla tranquebarica $(10.37 \%)$ dari sampel yang berjumlah 164 individu. Kepiting yang mendominasi adalah Scylla serrata. Kepiting bakau yang biasanya dipasarkan adalah kepiting yang memiliki berat $\geq 250$ gram per ekor dengan harga Rp. 35.000/kg.
\end{abstract}

Kata Kunci : Kepiting Bakau, Jenis atau morfologi, Kelimpahan.

\begin{abstract}
One of fisheries resources in Indonesia is mud crabs, but information in Central Tapanuli Regency about mud crabs in this area is still lacking, especially in numbers of species. To overcome these problems, needs a study of identification of mud crabs as well as its morphology and commercial value of mud crab. This research was carried out in January-Februari 2011 to find out the species and morphology, abundance and domination, and the commercial value of mud crabs at Central Tapanuli Regency, North Sumatera. Samples were the mud crabs landed in three TPI (Fish Landing Area) i.e Hajoran Village, Poriaha Village, and Sijago-jago Village at Central Tapanuli Regency. Mud crabs that caught by fisherman were identified and measured its morphometric, then analyzed the data. Fishermen were interviewed to find out the value of commercial and the price range of mud crabs. This research found three species of mud crabs, i.e Scylla serrata (63,41\%), Scylla olivacea (26,22\%), and Scylla tranquebarica (10,37\%) of 164 samples. The most dominant species was Scylla serrata. Mud crabs are usually marketed in the weight of $\geq 250 \mathrm{gr}$ per mud crab with price Rp. $35.000 / \mathrm{kg}$
\end{abstract}

Keyword : mud crabs, species and morphology, abundance.

\section{PENDAHULUAN}

Kepiting bakau adalah salah satu potensi yang ada di hutan mangrove dan belum banyak diketahui. Kepiting bakau termasuk sumberdaya perikanan pantai yang mempunyai nilai ekonomis penting dan mempunyai harga yang mahal (Afrianto dan Liviawaty, 1992). Setiap 100 gram daging kepiting mengandung protein sebesar 13,6 gram, lemak 3,8 gram dan air sebanyak 68,1 gram (Kordi, 2000). Oleh karena itu permintaan akan kepiting bakau terus meningkat baik untuk konsumsi dalam negeri maupun untuk keperluan ekspor. Permintaan yang terus meningkat tersebut dipenuhi melalui penangkapan di alam (Moosa et al, 1985).

Wilayah pesisir laut dan kelautan serta sumberdaya alam yang terkandung di dalamnya merupakan tumpuan pembangunan bagi Kabupaten Tapanuli Tengah. Kabupaten Tapanuli Tengah memiliki potensi kekayaan dan sumberdaya serta jasa-jasa lingkungan yang beragam seperti perikanan, perkebunan, pertanian, serta kawasan pariwisata.

Salah satu upaya pengelolaan sumberdaya perikanan khususnya bagi Kabupaten Tapanuli Tengah, Sumatera Utara dan umumnya kabupaten/ kota lainnya di Indonesia adalah meningkatkan pertumbuhan ekonomi secara berkesinambungan dengan mengoptimalkan pemanfaatan sumberdaya alam yang terdapat di wilayah daratan, pesisisir dan lautan tanpa merusak daya dukung alamnya, sehingga dapat mengembangkan serta memanfaatkan sumberdaya alam yang baru. Beberapa bentuk ancaman kelestarian keanekaragaman hayati antara lain karena pencemaran, eksploitasi sumber daya alam untuk perdagangan, penebangan hutan dan sebagainya. Pesatnya pembangunan di segala bidang banyak menimbulkan 
ketidaksesuaian antara kepentingan pelestarian alam di satu sisi dan eksploitasi sumberdaya alam untuk memenuhi sektor ekonomi di sisi lainnya.

Masalah yang ada di Kabupaten Tapanuli Tengah adalah belum adanya data akurat tentang kepiting bakau yang merupakan sumber mata pencaharian bagi para nelayan yang diharapkan dapat menjadi bahan pertimbangan dalam menentukan kebijakan yang tepat bagi pengelolaan komoditas perikanan kepiting bakau, sehingga kesetimbangan populasi dapat terpelihara dengan baik. Sehubungan dengan hal tersebut, maka penelitian mengenai inventarisasi jenis kepiting bakau di Kabupaten Tapanuli Tengah dapat diketahui dengan melakukan identifikasi morfologi kepiting.

Penelitian kepiting bakau di wilayah Kabupaten Tapanuli Tengah ini bertujuan sebagai berikut mengetahui jenis dan morfologi kepiting bakau, mengetahui kelimpahan dan jenis kepiting bakau yang mendominasi, mengetahui berat komersil dan kisaran harga kepiting bakau.

\section{MATERI DAN METODE}

Pengambilan sampel diambil dari hasil tangkapan nelayan yang di daratkan di 3 (tiga) TPI Kabupaten Tapanuli Tengah, sampel acak sederhana dimana setiap sampling unit terdiri dari kumpulan/kelompok elemen (Supranto, 2000). Dalam hal ini sampel telah dikelompokkan berdasarkan warna, lalu dipisahkan lagi berdasarkan pengamatan pada duri frontal margin dan duri pada carpus, kemudian dilakukan pengukuran morfometrik. Kepiting yang tidak memiliki kelengkapan tubuh tidak dilakukan pengukuran morfometrik. Untuk mengukur morfometrik kepiting digunakan jangka sorong dengan ketelitian 0,1 mm serta timbangan untuk mengukur berat kepiting. Bagian-bagian kepiting yang diukur yaitu lebar karapas atau Carapace width (CW), Internal carapace width (ICW), Carapace length (CL), Frontal median spine height (FMSH), Frontal width (FW), Inner carpus spine (ICS), dan Outer carpus spine (OCS).

Data yang diperoleh selanjutnya dianalisa sesuai hasil penelitian Keenan, et al (1998) dengan mengetahui karakter morfologi yang digunakan untuk identifikasi kepiting bakau, setelah itu data dibandingan dengan rata-rata dan standar deviasi dari tiga rasio mofologi dan bentuk duri antara mata untuk membedakan spesies kepiting bakau.

\section{HASIL}

Kabupaten Tapanuli Tengah merupakan salah satu kabupaten yang berada di Propinsi Sumatera Utara. Jarak dari ibukota propinsi $\pm 359 \mathrm{~km}$ dengan luas wilayah $6.194,98 \mathrm{~km}^{2}$ dengan perincian luas daratan $2.194,98 \mathrm{~km}^{2}$ dan luas lautan $4000,00 \mathrm{~km}^{2}$ yang terdiri dari 15 kecamatan dan 176 desa/kelurahan. Wilayahnya berada $0-1.266$ meter di atas permukaan

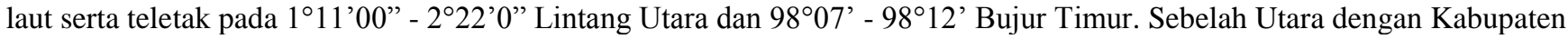
Aceh Singkil Propinsi Nanggroe Aceh Darussalam, sebelah Selatan dengan Kabupaten Tapanuli Selatan, sebelah Timur dengan Kabupaten Tapanuli Utara, sebelah Barat dengan Kota Sibolga dan Samudera Indonesia.

Hasil yang diperoleh dari pengumpul kepiting bakau di 3 (tiga) TPI dapat dilihat dalam Tabel 1.

Tabel 1. Hasil tangkapan kepiting bakau tiap TPI

\begin{tabular}{ccccc}
\hline \multirow{2}{*}{ Sampling } & Tanggal & \multicolumn{3}{c}{ Jumlah Tangkapan } \\
\cline { 3 - 5 } & & $\begin{array}{c}\text { Desa Sijago-jago } \\
\text { (Kamis) }\end{array}$ & $\begin{array}{c}\text { Desa Poriaha } \\
\text { (Selasa) }\end{array}$ & $\begin{array}{c}\text { Desa Hajoran } \\
(\text { Sabtu) }\end{array}$ \\
\hline 1 & 11 Januari 2011 & - & 12 & - \\
2 & 13 Januari 2011 & 10 & - & - \\
3 & 15 Januari 2011 & - & - & 18 \\
4 & 20 Januari 2011 & 9 & - & - \\
5 & 22 Januari 2011 & - & - & - \\
6 & 25 Januari 2011 & - & - & - \\
7 & 29 Januari 2011 & - & 11 & - \\
8 & 01 Februari 2011 & - & - & - \\
9 & 05 Februari 2011 & - & - & - \\
10 & 08 Februari 2011 & - & - & - \\
11 & 12 Februari 2011 & - & - & - \\
12 & 17 Februari 2011 & 12 & - & 71 \\
13 & 19 Februari 2011 & - & 56 & - \\
14 & 24 Februari 2011 & 6 & 37 &
\end{tabular}


Dari 164 sampel yang diperoleh dari beberapa pengumpul di Kabupaten Tapanuli Tengah terdapat 3 jenis kepiting bakau Scylla serrata memiliki persentase terbesar, yaitu 63,41\%. Kemudian Scylla olivacea 26,22 \% dan Scylla tranquebarica 10,37 \%. Scylla paramamosain tidak ditemukan di Kabupaten Tapanuli Tengah, Sumatera Utara. Untuk lebih jelasnya dapat dilihat dari Gambar 1.

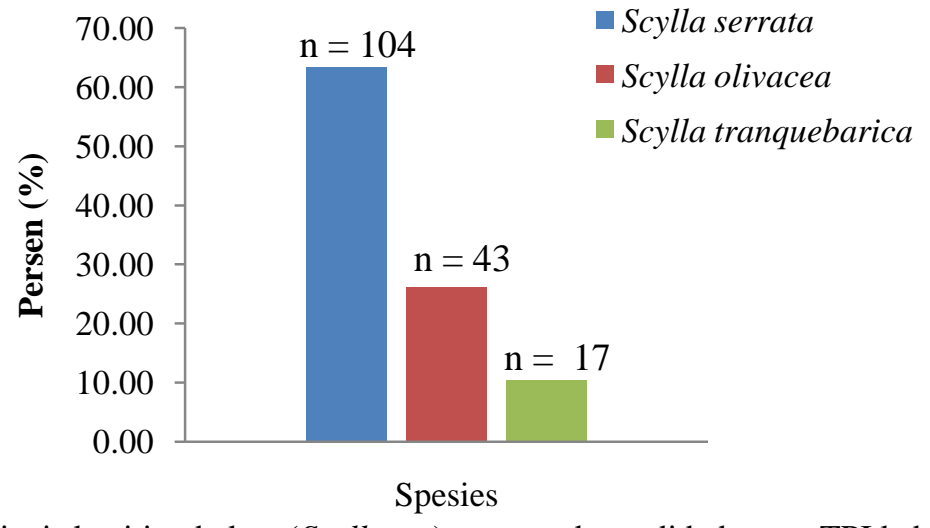

Gambar 1. Diagram persentase jenis kepiting bakau (Scylla sp.) yang terdapat di beberapa TPI kabupaten Tapanuli Tengah

Pengelompokan jenis ini didasarkan pada ciri spesifik dari frontal margin dari carpus. S. serrata memiliki duri tajam pada frontal marginnya dan dua duri nyata di carpus nya. S. olivacea memiliki duri tumpul di frontal marginnya dan satu duri mereduksi pada carpusnya, $S$. tranquebarica memiliki duri tumpul pada frontal marginnya dan dua duri nyata pada carpusnya. S. serrata diperoleh 104 sampel, 16 individu berwarna hijau kehitaman, 12 individu berwarna hijau kecoklatan, sedangkan 76 individu lainnya berwarna hijau tua pada karapas dan hijau kebiruan pada capitnya. S. olivacea diperoleh 43 individu. S. olivacea bewarna hijau kecoklatan sampai merah kecoklatan, hampir serupa dengan S. serrata. Pada S. olivacea terdapat garis-garis bewarna coklat kemerahan hampir pada seluruh bagian tubuhnya terkecuali abdomen. Dari 43 individu, diperoleh 14 sampel berwarna hijau tua, 10 sampel berwarna coklat kehitaman, 19 sampel berwarna coklat kemerahan. $S$. tranquebarica diperoleh 17 individu. S. tranquebarica memiliki warna hijau tua dan coklat kehitaman pada karapasnya, dari 17 individu diperoleh 9 (sembilan) sampel yang berwarna hijau tua dan 8 (delapan) sampel yang berwarna hijau kecoklatan. Sampel S. tranquebarica yang diperoleh memiliki warna hijau ungu kecoklatan pada capitnya. Untuk lebih jelasnya dapat dilihat pada Tabel 2 .

Tabel 2. Hasil identifikasi kepiting bakau berdasarkan warna yang terdapat di daerah Kabupaten Tapanuli Tengah

\begin{tabular}{ll}
\hline \multicolumn{1}{c}{ Spesies } & \multicolumn{1}{c}{ Warna } \\
\hline S. serrata $(\mathrm{n}=104)$ & $\begin{array}{l}\text { Hijau kehitaman (gelap), hijau kecoklatan, dan hijau tua, capit berwarna hijau } \\
\text { kebiruan. }\end{array}$ \\
S. olivacea $(\mathrm{n}=43)$ & $\begin{array}{l}\text { Hijau kecoklatan, cokelat kemerahan, dan cokelat kehitaman (gelap), capit } \\
\text { berwarna merah bata. }\end{array}$ \\
S. tranquebarica $(\mathrm{n}=17)$ & Hijau kecoklatan dan hijau tua, capit berwarna hijau ungu kecoklatan. \\
\hline
\end{tabular}

Ukuran panjang karapas pada Scylla dari seluruh sampel yang diperoleh adalah 4,51 cm sampai 12,33 cm. Ukuran lebar karapasnya berkisar dari $8,56 \mathrm{~cm}$ sampai $18,45 \mathrm{~cm}$. Jenis $S$. serrata panjang karapas memiliki ukuran yaitu $4,51 \mathrm{~cm}$ sampai $11,79 \mathrm{~cm}$ dan untuk lebar karapasnya berkisar dari $8,56 \mathrm{~cm}$ sampai $17 \mathrm{~cm}$. Hubungan panjang dan lebar S.serrata dapat dilihat pada Gambar 2.

Untuk S. olivacea panjang karapas memiliki ukuran dari 4,91 cm sampai 11,79 cm untuk lebar memiliki ukuran 7,56 cm sampai 15,21 cm. Hubungan panjang dan lebar karapas pada S. olivacea dapat dilihat pada Gambar 3.

Terakhir, untuk $S$. tranquebarica memiliki ukuran panjang karapas 4,91 cm sampai 12,33 cm, dan lebar karapasnya dari $8,26 \mathrm{~cm}$ sampai $18,45 \mathrm{~cm}$. Hubungan panjang dan lebar karapas $S$. tranquebarica dapat dilihat pada Gambar 4 . Serta frontal margin dan carpus untuk masing masing jenis Scylla dapat dilihat pada Tabel 3.

Berat Scylla yang diperoleh dari penelitian memiliki ukuran yang beragam yaitu dari 90 gram sampai 1250 gram. Sedangkan gambaran ukuran berat masing masing jenis antara lain untuk jenis S. serrata sebesar 90 gram sampai 1250 gram, S. olivacea sebesar 125 gram sampai 650 gram, dan S. tranquebarica sebesar 90 gram sampai 680 gram.

Berat rata-rata tiap spesies yang tertangkap oleh nelayan pada tiga TPI di Kabupaten Tapanuli Tengah adalah sebagai berikut $S$. tranquebarica memiliki berat rata-rata 300,58 gram dengan nilai tengah 250 gram. Berat S. tranquebarica 
tersebar paling banyak pada kisaran 122,50-515 gram dan berat maksimal sebesar 680 gram. S. serrata memiliki berat ratarata 344,95 gram dengan nilai tengah 260 gram. Berat $S$. serrata tersebar paling banyak pada kisaran 185-500 gram, namun outlier 38 menunjukkan berat ekstrim sebesar 1.250 gram. Sedangkan S. olivacea memiliki berat rata-rata 286,39 gram dengan nilai tengah 250 gram, berat tersebar paling banyak pada kisaran 180-400 gram dan berat maksimal sebesar 650 gram (Gambar 5.)

Lebar karapas rata-rata $S$. tranquebarica memiliki lebar karapas rata-rata $11,55 \mathrm{~cm}$ dengan nilai tengah $11,61 \mathrm{~cm}$, dimana data tersebar paling banyak pada kisaran $8,81-13,86 \mathrm{~cm}$ dan lebar karapas maksimal sebesar 18,45 cm. Lebar karapas $S$. serrata rata-rata $10,76 \mathrm{~cm}$ dengan nilai tengah $10,72 \mathrm{~cm}$, data tersebar paling banyak pada kisaran 8,87-11,87 cm, dan outlier 16 menunjukkan lebar karapas yang bisa dicapai sebesar $17 \mathrm{~cm}$. Lebar karapas S. olivacea rata-rata 10,66 cm dengan nilai tengah $11,20 \mathrm{~cm}$ dan data tersebar paling banyak pada kisaran 9-11.61 $\mathrm{cm}$ dan lebar maksimalnya sebesar $15,21 \mathrm{~cm}$ (Gambar 6.)

Panjang ICW S. tranquebarica rata-rata $11.10 \mathrm{~cm}$ dengan nilai tengah $11.32 \mathrm{~cm}$ dan data tersebar paling banyak pada kisaran 8.45-13.56 cm, panjang ICW maksimal sebesar $17.00 \mathrm{~cm}$. Untuk $S$. serrata rata-rata $9,98 \mathrm{~cm}$ dengan nilai tengah $9,915 \mathrm{~cm}$, data tersebar paling banyak pada kisaran $8,04-11,05 \mathrm{~cm}$, dan outlier 16 menunjukkan panjang ICW yang bisa dicapai sebesar $16,30 \mathrm{~cm}$. Panjang ICW S. olivacea rata-rata $9,89 \mathrm{~cm}$ dengan nilai tengah $10,25 \mathrm{~cm}$ dan data tersebar paling banyak pada kisaran 8,4-10.85 cm dan panjang ICW maksimal sebesar $14.49 \mathrm{~cm}$ (Gambar 7.)

Panjang karapas atau CL $S$. tranquebarica rata-rata $62,65 \mathrm{~mm}$, nilai tengah $7,71 \mathrm{~cm}$ dan data tersebar paling banyak pada kisaran 5,35-10.17 cm dan panjang karapas maksimal sebesar $12.33 \mathrm{~cm}$. Untuk $S$. rata-rata 7,50 cm, nilai tengah 7,21 cm, data tersebar paling banyak pada kisaran 5,41-8.87 cm, dan panjang karapas maksimal sebesar $12.33 \mathrm{~cm}$. Panjang karapas $S$. olivacea rata-rata 7,40 cm, nilai tengah 7,21 cm dan data tersebar paling banyak pada kisaran 5,40-8.87 $\mathrm{cm}$ dan panjang karapas maksimal sebesar $11.79 \mathrm{~cm}$ (Gambar 8.).

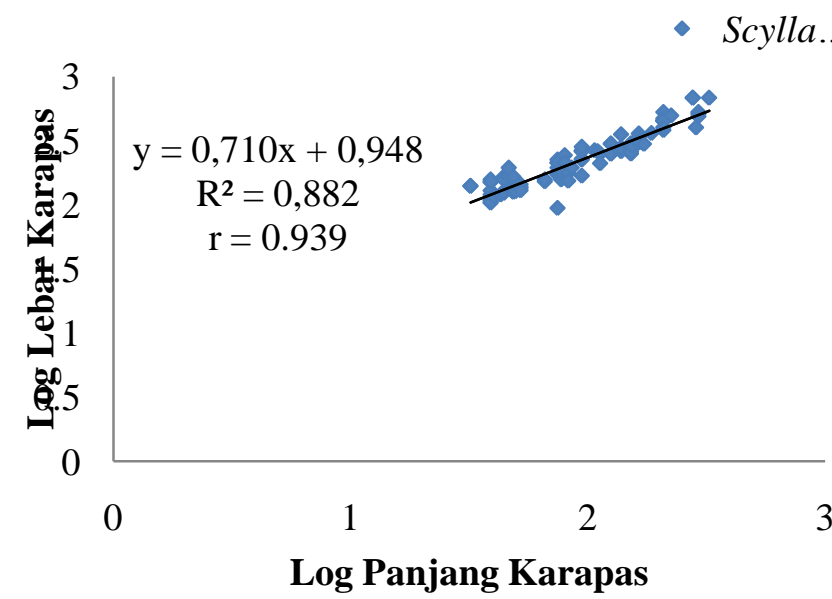

Gambar 2. Hubungan panjang dan lebar S. Serrata

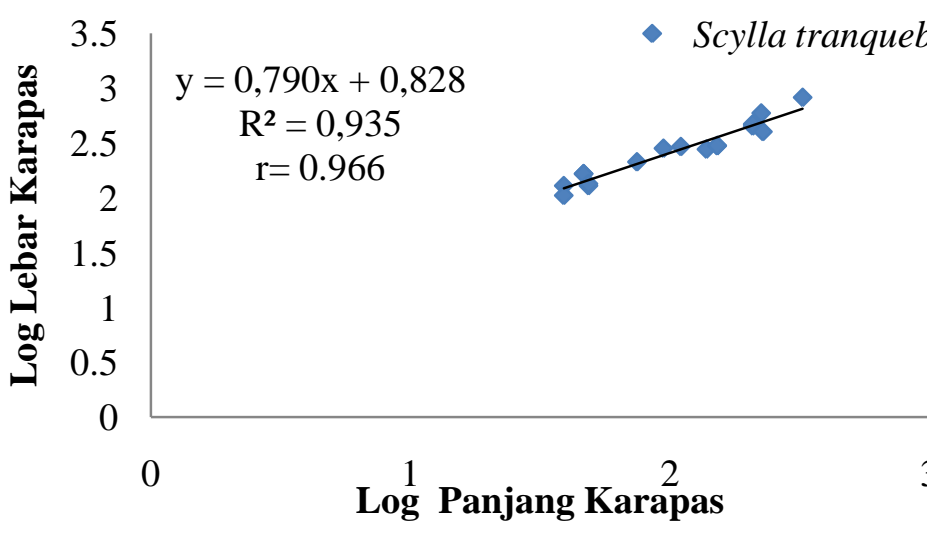

Gambar 4. Hubungan panjang dan lebar S. tranquebarica

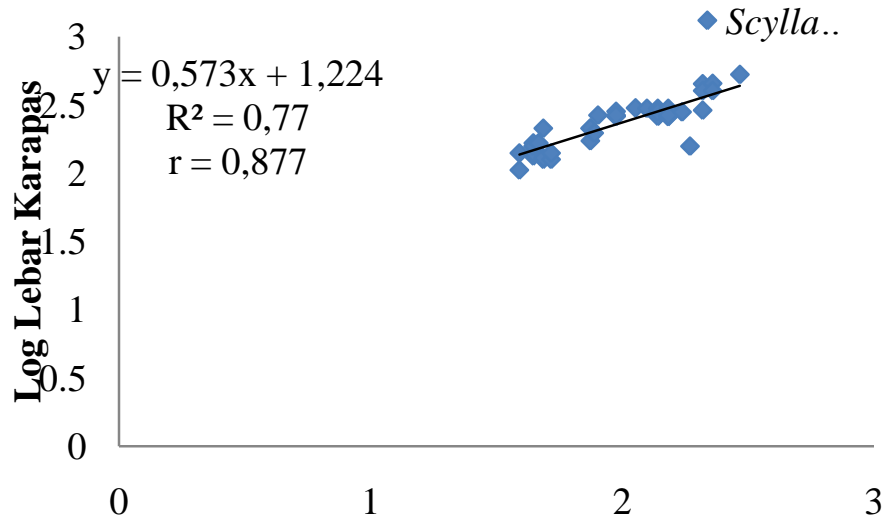

Log Panjang Karapas

Gambar 3. Hubungan panjang dan lebar S. Olivacea

- Scylla tranquebarica

3 
Tabel 3. Bagian tubuh kepiting bakau yang digunakan sebagai penentu jenis

\begin{tabular}{lcc}
\hline \multicolumn{1}{c}{ Jenis } & Gigi frontal margin & Duri carpus \\
\hline S. serrata & Tajam & Tidak mereduksi (2 duri) \\
S. olivacea & Tumpul & Mereduksi (1 duri) \\
S. tranquebarica & Tumpul & Tidak mereduksi (2 duri) \\
\hline
\end{tabular}

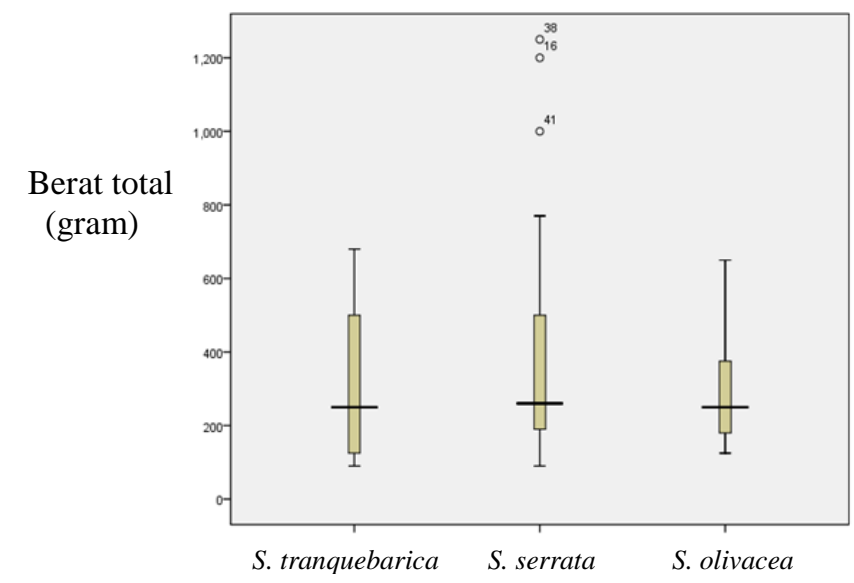

Gambar 5. Boxplot berat tiap spesies

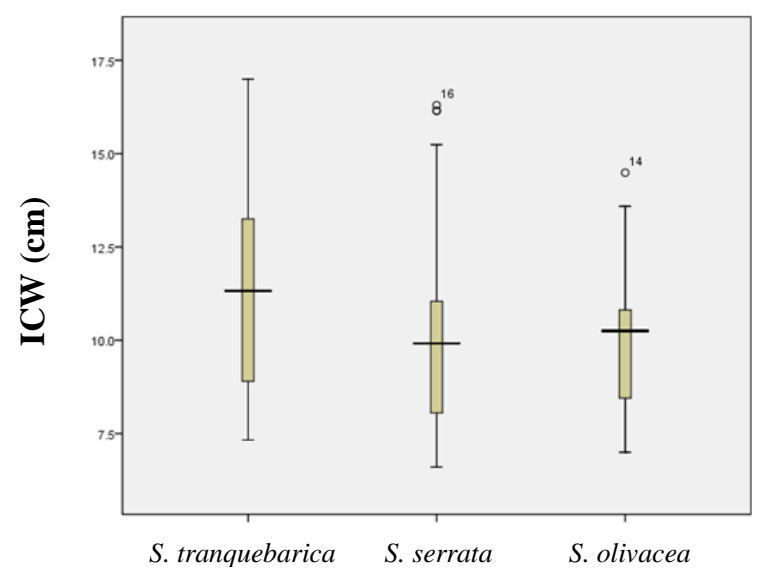

Gambar 7. Boxplot ICW tiap spesies

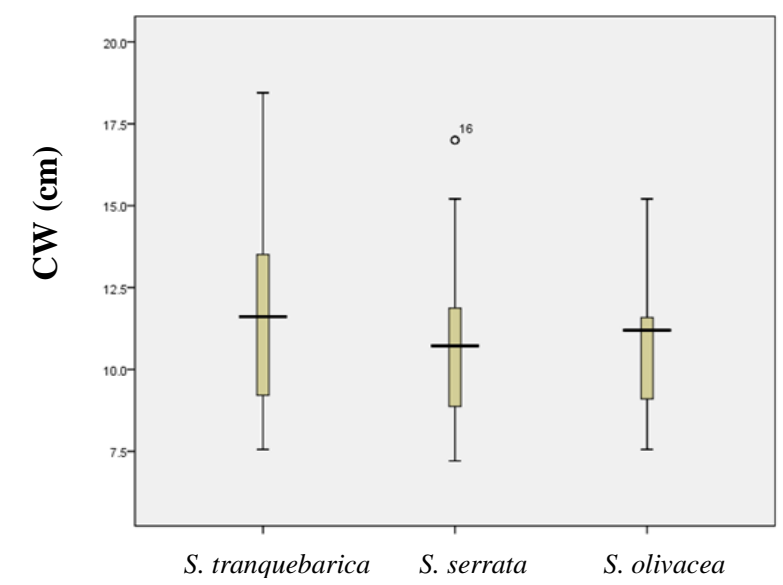

Gambar 6. Boxplot CW tiap spesies

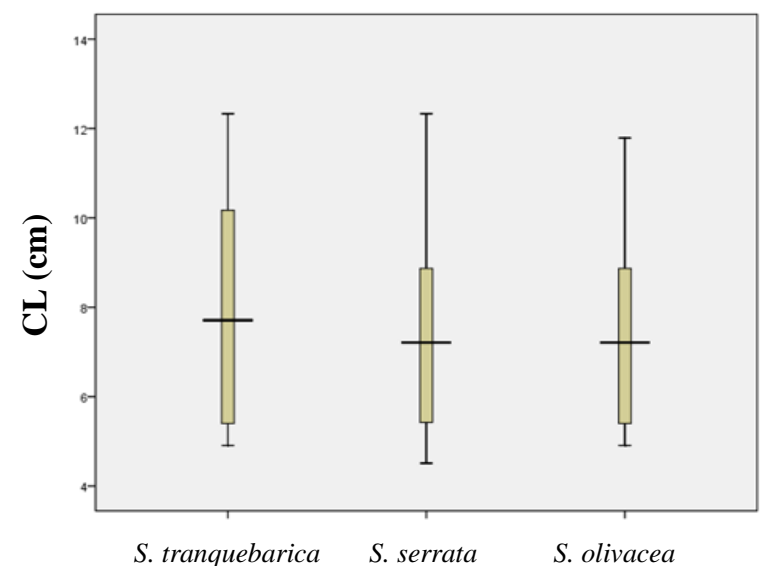

Gambar 8. Boxplot CL tiap spesies

Adapun rata-rata dan standar deviasi dari beberapa rasio morfologi dan bentuk duri antara mata untuk membedakan ketiga spesies kepiting bakau yang tertangkap selama penelitian, dapat dilihat pada Tabel 4. dan Gambar 9-11.

Tabel 4. Rata-rata dan standar deviasi dari beberapa rasio morfologi dan bentuk duri antara mata ketiga spesies kepiting bakau

\begin{tabular}{clccc}
\hline \multirow{2}{*}{ No. } & \multirow{2}{*}{ Rasio } & \multicolumn{3}{c}{ Rata-rata \pm SD } \\
\cline { 3 - 5 } & & S. tranquebarica & S. serrata & S. Olivacea \\
\hline 1. & CW & $11,55 \pm 3,033$ & $10,76 \pm 2,299$ & $10,66 \pm 1,822$ \\
2. & ICW & $14,6 \pm 3,105$ & $9,98 \pm 2,275$ & $9,89 \pm 1,818$ \\
3. & CL & $7,8 \pm 2,402$ & $7,50 \pm 2,050$ & $7,4 \pm 1,926$ \\
4. & FMSH/FW & $0,06 \pm 0,015$ & $0,068 \pm 0,017$ & $0,056 \pm 0,016$ \\
5. & FW/ICW & $0,491 \pm 0,099$ & $0,533 \pm 0,111$ & $0,519 \pm 0,094$ \\
6. & ICS/OCS & $1,006 \pm 1,477$ & $0,673 \pm 0,188$ & $0,714 \pm 0,107$ \\
\hline
\end{tabular}




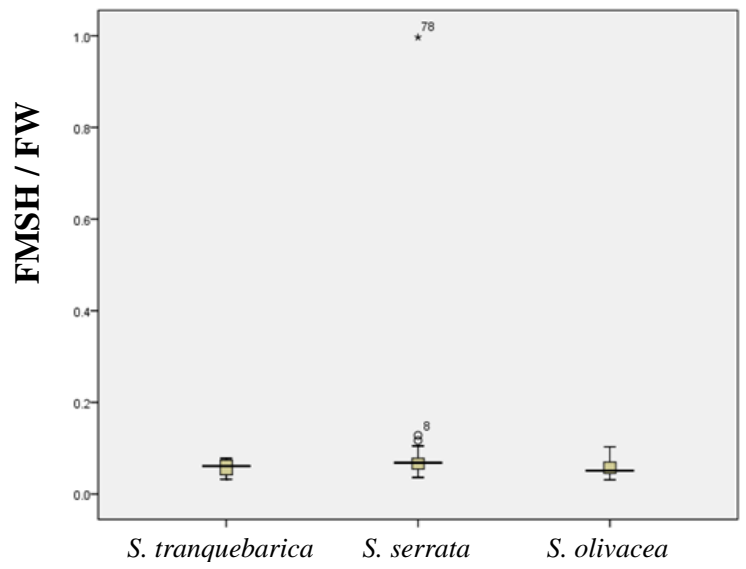

Gambar 9. Boxplot FMSH/FW tiap spesies

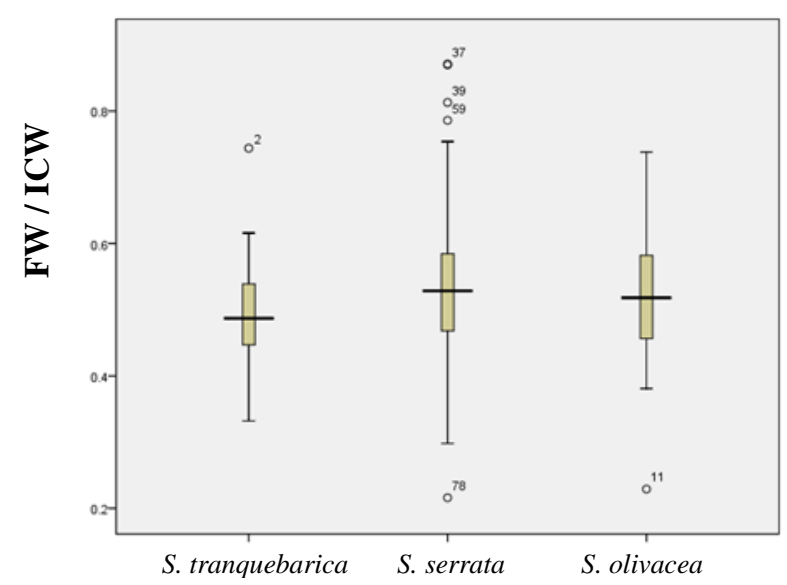

Gambar 10. Boxplot FW/ICW tiap spesies

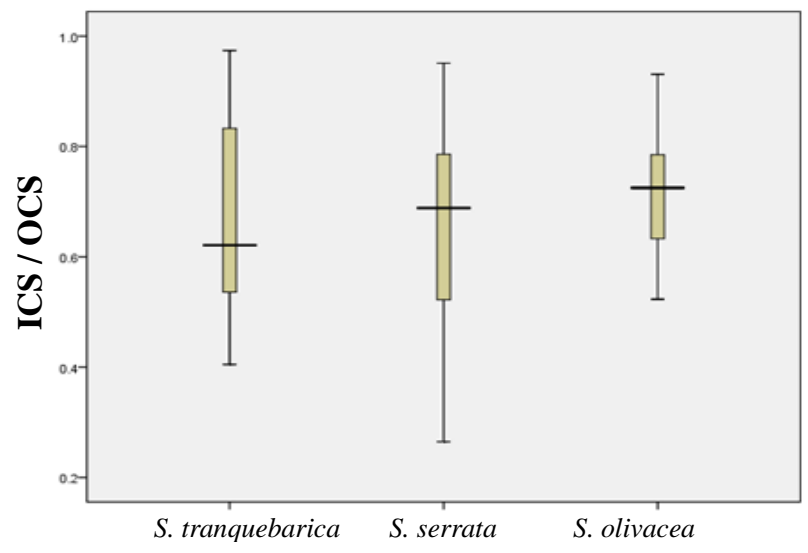

Gambar 11. Boxplot ICS/OCS tiap spesies

Pada Gambar 9. boxplot FMSH/FW, Scylla tranquebarica memiliki rata-rata 0,059 cm, nilai tengah $0.061 \mathrm{~cm}$, dan data tersebar paling banyak pada kisaran 0,042-0,075 cm. Scylla serrata memiliki rata-rata 0,068 cm, nilai tengah $0,068 \mathrm{~cm}$, dan data tersebar paling banyak pada kisaran $0.054-0.78 \mathrm{~cm}$. Scylla olivacea memiliki rata-rata $0,056 \mathrm{~cm}$, nilai tengah 0,051 $\mathrm{cm}$, dan data tersebar paling banyak pada kisaran $0,045-0,070 \mathrm{~cm}$.

Pada Gambar 10. boxplot FW/ICW, Scylla tranquebarica memiliki rata-rata $0,490 \mathrm{~cm}$, nilai tengah $0,487 \mathrm{~cm}$, dan data tersebar paling banyak pada kisaran $0,424-0,541 \mathrm{~cm}$. Scylla serrata memiliki rata-rata $0,532 \mathrm{~cm}$, nilai tengah $0,528 \mathrm{~cm}$, dan data tersebar paling banyak pada kisaran $0,466-0,584 \mathrm{~cm}$. Scylla olivacea memiliki rata-rata 0,522 cm, nilai tengah $0,518 \mathrm{~cm}$, dan data tersebar paling banyak pada kisaran $0.445-0.601 \mathrm{~cm}$.

Pada Gambar 11. boxplot ICS/OCS, Scylla tranquebarica memiliki rata-rata $0.669 \mathrm{~cm}$, nilai tengah $0,621 \mathrm{~cm}$, dan data tersebar paling banyak pada kisaran 0,529-0.689 cm. Scylla serrata memiliki rata-rata 0, $660 \mathrm{~cm}$, nilai tengah $0,688 \mathrm{~cm}$, dan data tersebar paling banyak pada kisaran $0,520-0,786 \mathrm{~cm}$. Scylla olivacea memiliki rata-rata $0,713 \mathrm{~cm}$, nilai tengah $0,725 \mathrm{~cm}$, dan data tersebar paling banyak pada kisaran $0,622-0,786 \mathrm{~cm}$.

Adapun kisaran masing-masing bagian kaki dan abdomen dari sampel yang diperoleh adalah pada bagian kaki Scylla 3PML (Merus Propodus Lenght) berkisar antara $2.89 \mathrm{~cm}$ sampai $4.88 \mathrm{~cm}, 5 \mathrm{PL}$ (panjang kaki kipas) berkisar antara 2,02 cm sampai $4.52 \mathrm{~cm}$, 5PW (lebar kaki kipas) berkisar antara $1.41 \mathrm{~cm}$ sampai $2.77 \mathrm{~cm}$, ICS (Inner Carpus Spine) berkisar antara $0.12 \mathrm{~cm}$ sampai $1.32 \mathrm{~cm}$, OCS (Outer Carpus Spine) berkisar antara $0.17 \mathrm{~cm}$ sampai $1.91 \mathrm{~cm}$, CDL (Dactyl Corpus Lenght) berkisar antara $3.20 \mathrm{~cm}$ sampai $4.74 \mathrm{~cm}$, CPD (Corpus Propodus Depht) berkisar antara $2.25 \mathrm{~cm}$ sampai $5.67 \mathrm{~cm}$, CPL (Corpus Propodus Lenght) berkisar antara $6.25 \mathrm{~cm}$ sampai $9.51 \mathrm{~cm}, \mathrm{CPW}$ (lebar Propodus) berkisar antara $3.21 \mathrm{~cm}$ sampai $6.84 \mathrm{~cm}$, serta pengukuran pada bagian perut kepiting yang terdiri dari Sternum Width (SW) berkisar antara 3,40 cm sampai $9,20 \mathrm{~cm}$ dan abdomen width (AW) $1,90 \mathrm{~cm}$ sampai 7,41 cm.

Kepiting bakau tertangkap di Kabupaten Tapanuli Tengah Sumatera Utara biasanya dijual kepada pengumpul atau dikonsumsi sendiri, sehingga harga komoditas tersebut tidak mencapai harga pasar yang sesungguhnya. Kelompok ukuran pasaran kepiting bakau yang tertangkap selama penelitian dapat dilihat pada Tabel 5 . 
Tabel 5. Ukuran komersil kepiting bakau

\begin{tabular}{clcl}
\hline Jenis kelamin & \multicolumn{1}{c}{ Kisaran berat (gram) } & Jumlah /1 kg (ekor) & \multicolumn{1}{c}{ Harga/kg } \\
\hline Jantan & $100-150$ & 10 & - \\
& $200-250$ & 6 & - \\
& $250-300$ & 5 & Rp. 35.000 \\
& $350-400$ & 4 & Rp. 50.000 \\
& $\geq 400$ & 2 & Rp. 80.000 \\
\hline Betina & $250-350$ (bertelur) & 4 & Rp. 50.000 \\
& $350-500$ (bertelur) & 2 & Rp. 75.000 \\
& $\geq 1000$ (bertelur) & 1 & Rp. 100.000 \\
& $250-350$ (tdk bertelur) & 4 & Rp. 35.000 \\
& $350-500$ (tdkbertelur) & 2 & RP. 65.000 \\
& $\geq 1000$ & 1 & Rp. 85.000 \\
\hline
\end{tabular}

Beberapa hal yang perlu diketahui untuk menjual kepiting bakau kualitas ekspor kepada pengumpul adalah memiliki bentuk badan utuh dan capit tidak patah. Kepiting bakau jantan dengan berat 400 gram - $\geq 1000$ gram dibeli dari penangkap dengan kisaran harga minimal Rp. 80.000,- per kilogram sedangkan $\leq 400$ gram seharga Rp. 50.000,- per kilogram dan untuk kepiting bakau betina dengan berat 500 gram $-\geq 1000$ gram dibeli dari penangkap dengan kisaran harga minimal Rp. 100.000,- per kilogram, sedangkan $\leq$ dari 500 gram seharga Rp. 75.000/kg. Harga yang ditawarkan juga beragam berdasarkan permintaan pasar dengan musim/ ada tidaknya kepiting.

\section{PEMBAHASAN}

Jenis Scylla yang diperoleh pada saat penelitian ada tiga jenis yaitu, S.serrata, S. olivacea, S. tranquebarica. Jenis yang ditemukan dalam penelitian ini berdasarkan tajam atau tumpulnya gigi bagian frontal margin dan mereduksi atau tidaknya duri pada carpus di chelipednya.

Menurut Carpenter dan Niem (1998), duri pada carpus dan gigi pada frontal margin merupakan bagian dari morfologi kepiting bakau (Scylla spp.), yang merupakan penentu jenis Scylla. Pengelompokan Scylla diawali dengan gigi anterolateral akhir sama dengan gigi-gigi yang lain pada daerah ini. Kemudian mulai terbagi pada daerah carpus dari cheliped, dimana yang pertama, carpus dari cheliped terdiri dari dua duri atau hanya ada satu duri yang mereduksi pada permukaan luarnya, dan capit bewarna kuning dan orange. Kedua, carpus dari cheliped memiliki dua duri tajam pada permukaan luarnya, dan capit berwarna hijau atau ungu. Duri carpus pertama dipecah menjadi 2 (dua), terlihat dari bagian frontal pada karapasnya.

Jika memiliki duri tajam pada bagian frontal dan memiliki dua duri carpus yang juga tajam, maka ciri-ciri tersebut merupakan jenis $S$. serrata. Selain itu pada capit memiliki duri yang tajam dan warna karapas biasanya berwarna hijau tua sampai hijau kehitaman (gelap). Bagian luar capit berwarna hijau kebiruan dan memiliki pola marmer. Kaki renang baik jantan maupun betina memiliki pola yang sama (Carpenter dan Niem, 1998).

Jika bagian frontal terdiri dari duri tumpul dan capit memiliki duri-duri yang tumpul, begitu juga dengan duri pada carpusnya yang sama-sama mereduksi. Karapas biasanya berwarna coklat kemerahan hampir pada seluruh bagian tubuhnya. Capit dan kaki jalan berwarna merah bata tanpa pola (Matxujmura et al., 2000), maka ciri-ciri tersebut merupakan jenis $S$. olivacea.

Jika bagian frontal terdiri dari duri tumpul dan pada capit memiliki duri-duri yang tajam, begitu juga dengan carpusnya memiliki dua duri tajam. Karapas biasanya berwarna hijau tua atau coklat kehitaman. Capit dan kaki jalan berwarna ungu kecoklatan, pola tidak teratur, maka ciri-ciri tersebut merupakan jenis S. tranquebarica. Pada pleopod jantan terdapat pola marmer pada capit (Carpenter dan Niem, 1998). Tajam dan tumpulnya gigi pada daerah frontal margin dan carpus untuk masing masing jenis Scylla dapat dilihat pada (Tabel 8).

Menurut Keenan (1999) dalam mengidentifikasi jenis-jenis kepiting bakau, dapat dilihat dari warna pada karapas. Selain warna kepiting bakau (Scylla sp.) dikelompokkan berdasarkan ciri bagian frontal dan carpus yang memiliki dua warna. S. serrata memiliki warna lebih beragam. Carpenter dan Niem (1998) berpendapat bahwa warna karapas $S$. serrata adalah hijau kehitaman dan menurut $\mathrm{Ng}$ et al. (2001), mempunyai capit bewarna hijau kebiruan. Diperoleh 104 sampel $S$. serrata, 16 individu berwarna hijau kehitaman, 12 individu berwarna hijau kecoklatan, sedangkan 76 individu lainnya bewarna hijau tua pada karapas dan hijau kebiruan pada capitnya. Pendapat tentang warna karapas S. serrata, sesuai dengan pustaka yang ada, walaupun dalam warna ada beberapa ciri pokok yang tidak sesuai. Kemungkinan perbedaan warna tersebut disebabkan oleh habitat yang berbeda, baik sebagai tempat hidup maupun pada saat beruaya. 
S. olivacea diperoleh 43 individu. S. olivacea berwarna hijau kecoklatan sampai merah kecoklatan, hampir serupa dengan S. serrata. Pada S. olivacea terdapat garis-garis berwarna coklat kemerahan hampir pada seluruh bagian tubuhnya termasuk capit terkecuali perut. Dari 43 individu, diperoleh 14 sampel bewarna hijau tua, 10 sampel bewarna coklat kehitaman, 19 sampel berwarna coklat kemerahan. Pada capit mempunyai warna merah bata dan tidak mempunyai pola (polos). Pendapat tentang warna karapas S. olivacea, sesuai dengan pustaka yang ada. Menurut Keenan (1999), S. olivacea memiliki warna hijau coklat merah seperti karat, capit tidak mempunyai pola, bentuk karapas tidak begitu dalam. Menurut matxujmura et al (2000), S. olivacea memiliki kaki capit dan kaki jalan berwarna merah bata tanpa pola polygonal sampaiberwarna lebih gelap. Dari dua pustaka tersebut menandakan bahwa sampel yang diperoleh masuk klasifikasi kepiting S. olivacea.

Namun berbeda dengan pendapat Carpenter dan Niem (1998), S. olivacea memiliki warna kecokelatan sampai coklat kehijauan (kadang-kadang oranye). Pernyataan tersebut tidak sesuai dengan ciri-ciri sampel yang diperoleh. Perbedaan warna tersebut disebabkan oleh habitat yang berbeda, baik sebagai tempat hidup maupun pada saat beruaya ketika kepiting ini ditangkap.

S. tranquebarica diperoleh 17 individu. S. tranquebarica memiliki warna hijau tua dan coklat kehitaman pada karapasnya, dari 17 individu diperoleh 9 (sembilan) sampel yang bewarna hijau tua dan 8 (delapan) sampel yang berwarna hijau kecoklatan. Sampel $S$. tranquebarica yang di peroleh memiliki warna hijau ungu kecoklatan pada capitnya. Disesuaikan dengan pustaka yang ada, menurut Carpenter dan Niem (1998), menjelaskan bahwa S. tranquebarica disebut juga purple mud crab, karena memiliki warna ungu pada capit dan tidak terdapat pola. Warna karapas dari Scylla ini bewarna hijau tua atau coklat sampai hitam. Dari pustaka tersebut menandakan bahwa sampel yang diperoleh masuk klasifikasi kepiting $S$. tranquebarica.

Hasil penelitian warna kepiting bakau selalu beragam dan berbeda di setiap pengamatan. Perbedaan ini banyak sekali penyebabnya. Contohnya seperti habitat yang berbeda, faktor internal dan faktor eksternal sehingga ada parameterparameter tertentu yang memungkinkan perbedaan warna. Sehingga warna belum dapat digunakan sebagai pedoman pengelompokan jenis dari kepiting bakau (Scylla sp.).

Menurut Le Vay (2001), kepiting bakau banyak ditemukan didaerah estuari dan daerah pesisir yang terlindungi. Pada umumnya, populasi kepiting bakau berasosiasi dengan hutan mangrove. Namun, penyebaran dan kelimpahan 4 spesies kepiting bakau kemungkinan lebih kompleks.

Ukuran panjang dan lebar karapas untuk Scylla memiliki perbandingan $2: 3$ untuk panjang dan lebarnya. Grafik perbandingan panjang dan lebar karapas masing masing jenis pada Gambar 2-4 menggambarkan bahwa semakin besar ukuran panjang karapas, maka ukuran lebar karapasnya juga bertambah besar, walaupun pada ukuran panjang karapas tertentu, lebar karapasnya mengalami penurunan dari ukuran sebelumnya. Secara umum grafik tersebut akan naik, ketika panjang dan lebar karapas Scylla bertambah. Menurut Sudradjat (1992), mengenai pertumbuhan panjang dan lebar karapas, bahwa lebar karapas relatif lebih besar dibandingkan dengan pertambahan panjang karapas, pertambahan ukuran panjang dan lebar karapas dipengaruhi oleh proses moulting kepiting bakau.

Frontal width pada $S$. serrata memiliki kisaran dari $2,65 \mathrm{~cm}$ sampai $6,78 \mathrm{~cm}$, S. olivacea memiliki kisaran dari 3.78 cm sampai 7,32 cm dan $S$. tranquebarica memiliki kisaran dari 4,3cm sampai 7,22 cm. Salah satu bagian karapas ini merupakan satu-satunya variabel selain identifikasi (Carpenter dan Niem, 1998) yang panjangnya dijadikan patokan membedakan kelompok morfologi putih (dengan bentuk duri tajam) dengan kelompok morfologi hitam (dengan bentuk duri smooth) pada Scylla (Overton, 1999). Teori ini didukung sebelumnya oleh Chayarat dan Kaew-ridh (1984) dalam overton (1999), yang menyimpulkan bahwa frontal width pada white morph lebih panjang ukurannya bila dibandingkan dengan red dan green morph yang oleh Overton (1999) diganti menjadi black morph. Di sini kelompok putih termasuk jenis $S$. serrata, sedangkan kelompok hitam termasuk jenis $S$. olivacea dan S. tranquebarica. Dari hasil sampel yang diperoleh, ternyata sesuai dengan pernyataan Overton (1999).

Untuk tebal karapas akan bertambah apabila Scylla tersebut mengalami pertumbuhan. Tebal karapas ditentukan oleh cembungnya karapas, yang merupakan tingkat pertumbuhan karapas yang juga mempengaruhi panjang dan lebarnya. Bagi Scylla betina, semakin matang telur maka punggung karapasnya semakin cembung (Sudrajat,1992).

Dari 164 sampel, diperoleh jantan dengan kisaran berat 90-1200 gram, dan betina 90-1250 gram. Scylla yang diperoleh mulai dari yang berukuran kecil, sampai berukuran besar/dewasa. Untuk jantan disebut kepiting super dan betina ditandai dengan telur pada abdomen. Besarnya ukuran kepiting belum tentu berat, disebabkan oleh kemungkinan dari proses moulting Scylla, sehingga sering ditemukan ukuran Scylla yang besar, tetapi beratnya kecil.

S. serrata sebesar 90 gram sampai 1250 gram, S. olivacea sebesar 125 gram sampai 650 gram, dan S. tranquebarica sebesar 90 gram sampai 680 gram bukan merupakan patokan untuk masing-masing jenis. Ukuran di atas masih dibawah ukuran maksimal yang bisa dicapai masing-masing individu. Misalnya S. serrata dapat mencapai $3 \mathrm{~kg}(\mathrm{Ng}$, et al, 2001). Maupun ukuran $2 \mathrm{~kg}$ yang dapat dicapai S. tranquebarica (Carpenter dan Niem, 1998). Menurut Nybakken (1992), kepiting bakau (Scylla sp.) juga dapat mencapai ukuran besar yaitu $2 \mathrm{~kg} / \mathrm{ekor}$. Makanan utamanya di alam adalah organisme bentik 
jenis-jenis invertebrata sehingga sering dijumpai memakan sesamanya terutama yang sedang mengalami pergantian kulit atau dikenal dengan molting. Ukuran berat belum bisa dijadikan penentu jenis dari Scylla.

Rata-rata dan standar deviasi dari beberapa rasio morfologi dan bentuk duri antara mata ketiga spesies kepiting bakau lihat Tabel 9. dan Gambar 17-19. Kemudian dibandingkan dengan rata-rata dan standar deviasi hasil penelitian dari Keenan et al (1998). Terdapat beberapa nilai rata-rata dan standar deviasi yang hampir mendekati dengan referensi Keenan et al (1998).

Penentuan warna, ukuran berat, bentuk duri pada frontal margin dan carpus kepiting bakau belum bisa dijadikan sebagai penentu jenis dari Scylla, walaupun ada beberapa ciri dan spesifikasi yang sudah menunjukkan jenis kepiting bakau namun masih terjadi perbedaan nilai perbandingan morfologinya sehingga dilakukan penghitungan berdasarkan rasio menurut referensi dari Keenan et al (1998).

Kaki (periopoda) V Scylla memiliki bentuk seperti kipas, dimana periopoda III lebih panjang bila dibandingkan dengan periopoda II dan IV. Hal ini dimungkinkan dengan fungsinya sebagai kaki jalan. Berbeda dengan periopoda I dan $\mathrm{V}$, yang fungsinya untuk mencari makan dan berenang. Sedangkan abdomen memilik bentuk yang berbeda antara jantan dan betina. Panjang abdomen jantan dan betina hampir sama, tetapi untuk lebarnya berbeda, karena bentuk abdomen betina lebih melebar, sedangkan jantan meruncing (Gambar 20.).

Menurut Afrianto dan Liviawaty (1992), jenis kelamin kepiting sangat mudah ditentukan, yaitu dengan mengamati alat kelaminnya yang ada di bagian perut (dadanya). Pada. bagian perut (dada) kepiting jantan umumnya terdapat organ kelamin berbentuk segitiga yang sempit dan agak meruncing di bagian depan sedangkan organ kelamin kepiting betina berbentuk segitiga yang relatif lebar dan di bagian depannya agak tumpul (lonjong).

Kepiting bakau merupakan salah satu sumber devisa pendapatan daerah yang belum banyak menggunakan teknologi pada budidayanya dan masih dianggap sebagai sumberdaya alam yang diperuntukkan untuk ditangkap dalam memenuhi permintaan pasar. Kepiting bakau salah satu komoditi perikanan yang mudah dalam pemasaran asalkan sesuai dengan kriteria antara lain berat $250-\geq 1000 \mathrm{gr} / \mathrm{kg}$, bentuk badan utuh dan capit tidak patah.

Sistem pemasaran hasil produksi kepiting bakau ini belum sepenuhnya melalui mekanisme pasar yang baik. Kepiting bakau tertangkap di kabupaten Tapanuli tengah Sumatera Utara biasanya dijual kepada pengumpul atau di konsumsi sendiri, sehingga harga komoditas tersebut tidak mencapai harga pasar yang sesungguhnya.

Kepiting dari Kabupaten Tapanuli Tengah dipasarkan di beberapa kota besar di Indonesia yaitu Medan, Jakarta, Surabaya dan Bandung dengan harga Rp. 50.000/kg sampai Rp. 75.000/kg dan untuk permintaan luar negeri kepiting sebelumnya ditampung di pabrik (cold storage) di Kawasan Industri Medan (KIM), setelah memenuhi syarat ekspor dalam bentuk segar/hidup, beku, maupun dalam kaleng baru dikirim dalam kontainer dengan harga Rp. 80.000/kg,- sampai Rp. 120.000/kg. Permintaan pasar luar negeri Singapura, Hongkong, Taiwan dan Malaysia harganya pun lebih tinggi. Kepiting yang mempunyai harga tinggi diantaranya adalah kepiting bakau merah dan hitam dengan kriteria antara lain berat mencapai maksimal $\geq 1000$ gram, bentuk badan utuh dan capit tidak patah.

Harga kepiting tidak selalu sama setiap waktu maupun setiap daerah. Harga kepiting sering mengalami perubahan, hal ini disebabkan oleh permintaan pasar dan musim. Di daerah Bali kepiting bakau yang dibudidayakan mempunyai empat warna cangkang berlainan yang membedakan kualitas rasa dan harga. Warna merah atau hitam untuk jenis standar sedangkan warna biru atau hijau untuk kualitas super. Harga kepiting bakau, dengan warna cangkang merah atau hitam, berkisar Rp 80.000/kg sampai dengan Rp 150.000/kg tergantung ukurannya, untuk warna cangkang biru atau hijau di atas Rp 100 ribu sampai Rp 170.000/kg, sedangkan kepiting soka (kepiting cangkang lunak) harga berkisar antara di atas 125 200/kg (Munif, 2013)

Berbeda dengan harga kepiting di Pulau Kalimantan, kepiting tersebut diekspor dalam bentuk segar/hidup, beku, maupun dalam kaleng. Pada musim-musim tertentu harga kepiting melonjak karena permintaan yang juga meningkat terutama pada perayaan-perayaan penting seperti Imlek dan lain-lain. Pada saat-saat tersebut harga kepiting hidup di tingkat pedagang pengumpul dapat mencapai Rp.100.000,- per kg yang pada hari biasa hanya Rp.40.000 untuk grade CB (betina besar berisi/bertelur, ukuran >200 g/ekor) dan Rp.30.000 untuk LB (jantan besar berisi, ukuran >500g-1000g/ekor). Kepiting lunak/soka harganya dua kali lipat lebih tinggi. Di luar negeri, harga kepiting bakau grade CB dapat mencapai 8.40 U\$ - 9.70 U\$ per kg sedangkan LB dihargai $6.10 \mathrm{U} \$-9.00 \mathrm{U} \$$ per kg. Ukuran $\geq 1000$ gram (super crab) harganya $10.5 \mathrm{U} \$$ per kg (Luthfi, 2013).

\section{KESIMPULAN DAN SARAN \\ Kesimpulan}

Kesimpulan yang dapat diambil setelah melakukan penelitian ini adalah sebagai berikut :

1. Jenis kepiting bakau yang didapatkan di wilayah kabupaten Tapanuli Tengah Sumatera Utara adalah 3 (tiga) spesies yaitu Scylla serrata, Scylla olivacea dan Scylla tranquebarica 
2. Hasil persentase Scylla serrata sebesar $63.41 \%$, Scylla olivacea sebesar $26.22 \%$, dan Scylla tranquebarica $10.37 \%$ dari 164 individu. Kepiting yang mendominasi di wilayah Kabupaten Tapanuli Tengah Sumatera Utara adalah Scylla serrata.

3. Kepiting bakau dengan berat $\geq 250$ gram $/ \mathrm{kg}$ adalah komoditi perikanan yang sangat diminati dan mudah untuk Saran dipasarkan di dalam negeri maupun di ekspor, serta harga jualnya tergantung pada minat pasar dan musim.

Saran yang dapat saya berikan sesuai dengan penelitian ini adalah mengingat penelitian hanya dilakukan di Tempat Pendaratan Ikan (TPI) disarankan penelitian selanjutnya dapat lebih dikhususkan pada pola morfologi kepiting bakau (Scylla sp.) yang dihubungkan dengan lokasi sampling, sehingga kemungkinan diperoleh hasil yang lebih spesifik berdasarkan lokasi masing masing.

\section{Ucapan Terimakasih}

Pada kesempatan ini penulis mengucapkan banyak terimakasih kepada Drs. Ign. Boedi Hendrarto, MSc. PhD. dan Drs. Mustofa Nitisupardjo, MSi yang telah membantu dalam penyusunan penulisan ini, orangtua yang telah memberi support, materi maupun moril serta teman-teman yang turut berpartisipasi dalam penelitian ini.

\section{Daftar Pustaka}

Afrianto,E dan Liviawaty, 1992. Pemeliharaan Kepiting. Kanius. Yogyakarta.

Carpenter, K, and Niem, C.H. 1998. The Living Marine Resources of the western Central Pasific. Volume 2. Food and Agriculture Organization of the United Nations, Rome.

Kasry, A. 1991. Budidaya Kepiting Bakau dan Biologi Ringkas. Bhatara, Jakarta.

Keenan, C. P. And A. Blackshaw. 1998. Mud Crab Aquaculture and Biology. Australian Centre for International Agricultural Research. Canberra

1999. Aquaculture of the mud crab, genus Scylla. Past, Present and Future in: Mud Crab Aquaculture and Biology. Keenan and Blackshaw (Eds) ACIAR Proceedings.

LeVay, L. 2001. Ecology and Management of Mud Crab Scylla spp. Asian Fisheries Science 14: 101-111.

Luthfi, M. 2013. Harga Kepiting Merah dan Kepiting Biru di Nusantara. (http://rajakepiting.com). Diakses pada tanggal 16 Juni 2013.

Matxujmura,K., Sumadhiharga, O.K., and Tsuhamito, K. 2000. Field Guide to Lombok Island. Identification Guide to Marine Organism in Seagrass Beds of Lombok island Indonesian, Ocean Reasearch Institute, University of Tokyo, Tokyo.

Moosa, M.K, 1985. Kepiting Bakau (Scylla serrata Forskal) Dari Perairan Indonesia.

Proyek Studi Potensi Sumberdaya Alam Indonesia. Lembaga Oseanologi Nasional, Lembaga Ilmu Pengatahuan Indonesia. Jakarta.

Munif, A. 2013. Kepiting Budidaya lokal. Bali. (Http://www.balebengong.net diakses pada tanggal 16 Juni 2013)

Nazir, M. 2005. Metode Penelitian. Penerbit Ghallia Indonesia, Jakarta.

Ng, PKL., Lim, KKp., Murphy, DH., Morgany, T. Sivasothi, N. 2001. A Guide to Mangroves of Singapore. Raffles Museum of Biodiversity Research, The National University of Singapore \& The Singapore Science Center.

Overton, J.L. 1999. MOrphometrics and ecology of the mud crab (Scylla spp) from Shoutheast Asia. In Keenan, CP. And Blackshaw, A (Eds), Mud Crab Aquaculture and Biology, Australian Center for International Aquacultur Reasearch, Canberra.

Sudrajat, A. 1992. Jurnal Penelitian Budidaya Pantai. Badan Penelitian dan Pengembangan Pertanian, Badan Penelitian Perikanan Budidaya Pantai Maros, Indonesia, Sulawesi Selatan. 